\title{
A new colorimeter-cuvet for ultra-micro techniques
} because

In microtechniques the use of very small samples is often made impossible

(a) the concentration of the substance to be determined is too low; and/or

(b) the sensitivity of the analytical method is insufficient.

In colorimetric methods this means that the extinction of the resulting solution is too low.

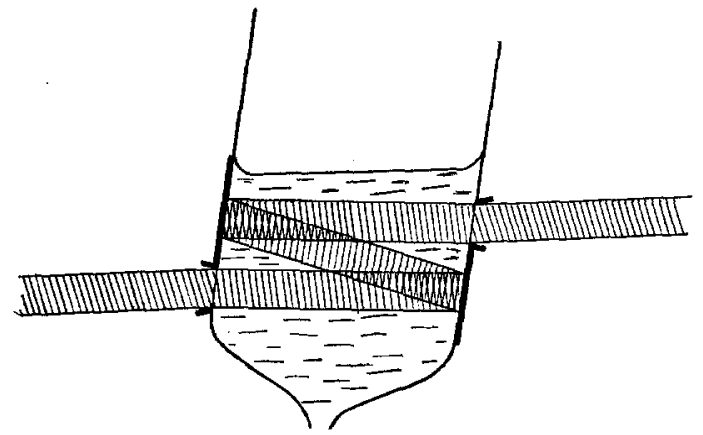

Fig. I. Double-reflection micracuvet.

TABLE I

INILUENCE OF RESIDUAL LIQUID AFTER EMFTYING

\begin{tabular}{|c|c|c|c|c|c|c|c|}
\hline $\begin{array}{c}\text { Evans } \\
\text { Blue }\end{array}$ & Water & $\begin{array}{c}\text { Evans } \\
\text { Blue }\end{array}$ & Water & $\begin{array}{l}\text { Evans } \\
\text { Blue }\end{array}$ & Water & $\begin{array}{l}\text { Evans } \\
\text { Blue }\end{array}$ & Water \\
\hline 0.400 & $\rightarrow 0.025$ & $\rightarrow 0.420$ & $\rightarrow 0.010$ & $\rightarrow 0.428$ & $\rightarrow 0.012$ & $\rightarrow 0.420$ & $\rightarrow 0,022$ \\
\hline 0.430 & 0.002 & 0.430 & 0.005 & 0.435 & 0.005 & $0.43^{8}$ & 0.000 \\
\hline 0.432 & 0.001 & $0.43^{8}$ & 0.001 & 0.437 & 0.002 & 0.437 & 0.003 \\
\hline 0.430 & 0.000 & 0.438 & 0.002 & 0.437 & $0.00 \mathrm{I}$ & 0.437 & 0.002 \\
\hline 0.430 & 0.002 & 0.433 & 0.001 & 0.437 & 0.002 & $0.43^{6}$ & $0.00 \mathrm{I}$ \\
\hline
\end{tabular}

For instance: the sensitivity of the bathophenantroline or TPTZ-method for the determination of iron is fairly high, the molar extinction of both complexes being of the order of 22.000.

However, the concentration of iron in serum is only about Ioo $\mu \mathrm{g} / \mathrm{IOO} \mathrm{ml}$, so that, given a colorimeter with cells of $I \mathrm{~cm}$ light path and a volume of $3 \mathrm{ml}$, one will need at least I $\mathrm{ml}$ serum to get an extinction of o.I.

In the micromodification of this method, cells of too $\mu \mathrm{l}$ volume and I $\mathrm{cm}$ light path are used. As the volume needed for a stationary cuvet with suction clearance is twice the capacity (rinsing once is necessary), the amount of the sample is roo $\mu$ l.

This may hardly be called an ultra-micro method, and for the purpose of improving all determinations which suffer from low extinction, we constructed a new microcuvet, equally simple in operation, requiring equally small volumes, but with a longer light path: a "double reflection cuvet". The light path in this cuvet, as may be seen in Fig. I, has roughly 3 times the normal length. 
As the quantity of light that passes through the cuvet is much lower than normal, it can only be used in colorimeters or spectrophotometers which have good electronic amplifiers and, by preference, photomultipliers.

The volume is IIo $\mu \mathrm{l}$. As with the normal cuvet, there is some residual liquid after emptying, but after rinsing once, the influence on the extinction is negligible. This may be scen in Table I, which gives the results of measuring 5 times a solution of Evans Blue, followed by 5 measurements of distilled water, and repeating this a number of times.

The optical path length was estimated by determining the ratio of the extinction of a solution in the reflection cell to the extinction of the same solution in a I-cm cell. In our last cell this was $29.4 \mathrm{~mm}$.

We expect this cell to improve the possibilities of colorimetric as well as fluorometric microdeterminations.

Laboratory for Clinical Microchemistry,

P. Reinouts van HaGa

Nieuree Gracht I37,

Utrecht (The Netherlands)

Received September Ist, 1963

Clin. Chim. Acta, $9(\mathbf{1 9 6 4 )} 97-98$

\section{A partially automated method for the determination of serum protein-bound iodine}

Since the publication of our paper ${ }^{1}$ dealing with this subject, the purity of Analar potassium chlorate obtainable in Great Britain has fallen below the standard necessary to give satisfactory blank values. We have found that the required standard of purity can be obtained by twice recrystallising from deionised water, Analar potassium chlorate manufactured by either British Drug Houses Ltd., Poole, Great Britain, or Hopkin and Williams Ltd., Chadwell Heath, Essex, Great Britain.

To recrystallise, dissolve with heating $500 \mathrm{~g}$ Analar potassium chlorate in $\mathrm{I} 1 \mathrm{of}$ deionised water, allow to cool slowly to room temperature, decant the supernatant, wash the crystals twice with small quantities of water, repeat the procedure and dry the crystals in an oven at $105^{\circ}$.

Biochemistry Department,

G. M. Widiowson

The General Hospital,

B. E. NORTHAM

Birmingham (England)

1 G. M. Widdowson and B. E. Northam, Clin. Chim. Acla, 8 (1963) 636.

Received October 23rd, 1963 